\title{
Examining the Relationship between Teachers' Individual Innovativeness and Technology Acceptance Status
}

\author{
Beyza ÖZKEŞ* \\ Kayseri Bahçeşehir College, Kayseri, Turkey \\ Sinan KAYA \\ Ondokuz Mayls University, Faculty of Communication, Samsun, Turkey,
}

\begin{abstract}
Technology acceptance status of teachers is regarded as an important structure for teacher to use technology in effective way while teaching and learning. That investigation of technology acceptance status of teachers in terms of individual differences is suggested by the researchers in literature. In this context, that creating the relationship between the features of individual innovativeness and technology acceptance status is considered to be so essential. By means of study it has been aimed to search for the relationship between individual innovativeness and technology acceptance status. Within this framework, it has been revealed the association between individual innovativeness and technology acceptance status. Relational survey model was used in this research and it's a descriptive research. The study group of research contains 115 female and 102 male, totally 217 teachers who works in different departments.In the research, "Individual Innovativeness Scale" was used for stating teachers' individual innovational features and "Technology Acceptance Scale for Teachers" was used the teaching-learning process to determine the status of teachers in technology acceptance. In the analysis of the data obtained, descriptive statistics, Pearson coefficient of correlation were used.As a consequence of the data obtained, according to individual innovation features, the teachers' individual innovativeness characteristics were determined to be early adopters category. Moreover, it has also been noticed that technology acceptance statuses of teachers were well. Basic correlation process defining whether there is a correlation among the features of individual innovativeness and technology acceptance status have shown that there is a correlation in a positive way, low and moderate levels and significant relationship between the features of individual innovativeness and technology acceptance status. It has been discovered that the factor between individual innovativeness features and the factor showing highest figure was perceived usefulness. And also the factor showing the lowest relation was self-efficacy.
\end{abstract}

Keywords: Individual innovativeness, technology acceptance, teacher characteristics. 


\section{Introduction}

The main purpose of the education for individuals and society is to adopt the people that they are part of the society in which they live and according to their age requirements to transfer knowledge and skills to adopt to new challenges for individuals. In order to achieve such a purpose first, individuals must be grown as people who can adapt to the developments occurring in the world and society and who having the necessary equipment to use their knowledge and skills usefully (Dilaver, 1996). Associated with the change in the field of technology and communication and increasing rapidly the amount of information with each passing day, Today is expressed as "computer age", "communication age" and "information age" (Akkoyunlu, 1998). Changes and developments in today's our world provide that the educational institutions which planning to the changings in line with the needs of the individual and society keep up with the changes and it provides that they develop their educational environments in this direction (Balay, 2004). The designing of educational environments as parallel to the developments, gaining positive opinion to people in terms of the use of the technology and the creation of the efficient technology plans in education are only possible to be in the process of development with an innovative understanding.

Information and communication technology which is become an important part of contemporary life is used to provide accessing to information, communicating with the environment by using electronic or digital tools (Siraj-Blatchford \& Siraj- Blatchford, 2003), the production of knowledge, the dissemination and management of information (Tinio, 2003). The rapid developments in the field of information and communication technologies contribute the development of education technologies and in this way, from the point of quality and quantity of education planning are carried out more efficiently (Kocasaraç, 2003). Raising qualified individuals by education is not limited only to gain technology identity. In the 21 st century, making a habit of lifelong learning, having skills of analysis, access, use and adaptation of information in different formats and environment, not only to share ideas and develop, but also willingness to be able to look at from different angles are must for the individuals (Partnership for 21st Century Skills, 2003). Problem solving, critical to interpret, communicate, collaborate on, and reach to information needed reliably and quickly, to use technology effectively and innovation is seen as the most important features of the innovative world of the 21st century (Partnership for 21st Century Skills, 2010). The achievement of the desired characteristic in education and the change and progresses which are expected to occur in the education will reach the desired target when they actively take part in practice (Fullan, 2007).

To be in constant development of technology leads that the basic elements of education, human, information and society show the development and change (Alkan, 1997). In this direction, associated with the rapid changes in science and technology, new methods of learning environment, material and technological equipment are included. Teachers have a primary role for the occurrence of the targeted changes in the process (Fullan, 2007). These innovations to be used in education must be used effectively and must be adopted as a priority by teachers who will train using these new (Usluel \& Mazman, 2010). Use of information and communication technology in schools as needed, to include it to education and training environment and implementation depend on teachers' motivation, knowledge and skills. However, to attract the interest of students towards information technology, to cause creating a positive or negative attitude $(\mathrm{Hu}$, Clark \& Ma, 2003), class lectures, presentations and ensure the proper integration of classroom technology for all other activities are the roles of teachers that should be overemphasized (Chen, Looi, \& Chen, 2009). In such a case, each 
passing day teachers must keep abreast of new information for constantly developing an applied science such as technology and teachers are required to have the necessary equipment on how to use this information in an educational environment. In this context, the most important features of a teacher should have, to be open to innovation and development, to be able to accept change and to renew itself constantly improving (Çelikten, Şanal \& Yeni, 2005; Şişman, 2006; Celep, 2004). To create harmony and perceptions of individuals and society to innovation and evolving situations First, teachers that is one of the most basic elements of education is expected to be innovative and responsive to the evolving situation individually. Fullan and Pomfret (1977) stated important connection among development of teachers with being innovative individuals. To reveal the targeted behaviors in education with technology and to give an idea to the creation of new goals as a result of development and changes are possible using the technology effectively. Technology provides great convenience and advantages in education, as in all areas. Integration of information and communication technologies for education became more important with each passing day and has become a subject that should be applied due to the impact of theoretical conversion in the teachinglearning process and technological developments. Because science, technology and environmental changes have become compulsory for people and society to renew, change and advance (Kabakc1, 2008). This obligation to assist the adoption of technology and innovation by teachers in the field of education offers opportunities for observation of behavior such as creating interest in students, innovative thinking and positive attitude towards science.

Vanderlinde and Braak (2011) indicate that the use of educational innovations actively in the educational process by teachers will be reflected positively on the students' educational outcomes due to the rapid changes in society and in education technology. Drent and Meelissen (2008) stated that personal entrepreneurship is an important situation for the innovative use of information and communication technologies in the learning process in accordance with the objectives. Also Teo (2009) stated that the use of technology properly in the teaching and learning process for the realization of effective and necessary purpose, closely associated with the factors affecting the teachers' technology acceptance. Usluel and Mazman (2010) represent that individuals would adapt more easily to new situations or against the innovation with the existence of factors that accelerate the process of adaptation for emerging growth and innovation by stating that linked the concept of technology adoption and innovation. Accordingly, it was emphasized that teachers can use the innovation easy and effectively and that a perception that they will benefit from the innovation will occur.

In the light of these assessments, teachers have a key role to create a positive perception towards change and innovation. First, teachers must adapt to this change and innovation process and gaining proficiency of teachers is required as having the necessary equipment. Technology acceptance status of teachers is seen as an important building to be able to use technology effectively and efficiently in the teaching-learning process. Investigation teachers' technology acceptance status in terms of individual differences is suggested by studies in the literature. In this context, determining the level of individual innovation and technology acceptance status of teachers and the relationship between these variables are seen as important in terms of revealing the existing situation.

\section{The aim of the research}

The purpose of this study is to determine the level of teachers' individual innovativeness, technology acceptance status and the relationship between them. In the line of this general purpose, the following research questions will be answered. 
(1) What is the level of individual innovativeness of teachers?

(2) What is technology acceptance status of teachers?

(3) Is there a significant relationship between the level of teachers' individual innovativeness and technology acceptance status of teachers?

\section{Method}

This section includes research model, data collection tools, study group, data analysis and interpretation of data.

\section{Research Model}

This study investigated the relationship between teachers' individual innovative characteristics and technology acceptance status is a descriptive study which conducted the relational screening model. The research model between two or more of the variables aiming to determine the presence or degree of change together is called as relational screening model (Karasar, 2009).

\section{Study Group}

The study group of the research is made up of 115 female and 102 male, totally 217 teachers who works in different departments. The gender of teachers, educational background, type of school, age, seniority, the level of instruction they work on, how long the information and communication technologies have been used by teachers, how long the information and communication technologies have been used in professional process by teachers, in-service of training or course participation related to information and communication technologies status of teachers are shown in Table1.

Table1. The Distribution of Teachers' Demographic Characteristics

\begin{tabular}{|c|c|c|c|}
\hline & & $\mathrm{N}$ & $\%$ \\
\hline \multirow{2}{*}{ Gender } & Female & 115 & 53,0 \\
\hline & Male & 102 & 47,0 \\
\hline \multirow{2}{*}{ Educational Background } & Undergraduate & 138 & 63,6 \\
\hline & Postgraduate & 79 & 36,4 \\
\hline \multirow{2}{*}{ Type of School } & Private School & 115 & 53,0 \\
\hline & State School & 102 & 47,0 \\
\hline \multirow{7}{*}{ Age } & $19-24$ & 18 & 8,3 \\
\hline & $25-30$ & 54 & 24,9 \\
\hline & $31-36$ & 90 & 41,5 \\
\hline & $37-42$ & 33 & 15,2 \\
\hline & $43-48$ & 12 & 5,5 \\
\hline & $49-54$ & 10 & 4,6 \\
\hline & $55+$ & 0 & 0 \\
\hline \multirow{7}{*}{ Seniority } & Less than 1 year & 14 & 6,5 \\
\hline & $1-4$ & 60 & 27,6 \\
\hline & $5-8$ & 56 & 25,8 \\
\hline & $9-12$ & 41 & 18,9 \\
\hline & $13-16$ & 15 & 6,9 \\
\hline & $17-20$ & 14 & 6,5 \\
\hline & $20+$ & 17 & 7,8 \\
\hline \multirow{4}{*}{ The level of instruction they work on } & Preschool education & 9 & 4,1 \\
\hline & Primary stage I & 60 & 27,7 \\
\hline & Primary stage II & 91 & 41,9 \\
\hline & Secondary stage (high schools) & 57 & 26,3 \\
\hline How long the information and & Not used & 3 & 1,4 \\
\hline
\end{tabular}




\begin{tabular}{|c|c|c|c|c|}
\hline \multirow{5}{*}{$\begin{array}{l}\text { communication technologies have been } \\
\text { used }\end{array}$} & Less than 1 year & & 1 & ,5 \\
\hline & $1-3$ years & & 6 & 2,8 \\
\hline & 4-7 years & & 83 & 38,2 \\
\hline & $8-11$ years & & 57 & 26,3 \\
\hline & $11 \ldots$ & & 67 & 30,9 \\
\hline \multirow{6}{*}{$\begin{array}{l}\text { How long the information and } \\
\text { communication technologies have been } \\
\text { used in professional process }\end{array}$} & Not used & & 2 & ,9 \\
\hline & Less than 1 year & & 20 & 9,2 \\
\hline & 1-3 years & & 95 & 43,8 \\
\hline & 4-7 years & & 53 & 24,4 \\
\hline & $8-11$ years & & 26 & 12,0 \\
\hline & $11 \ldots$ & & 21 & 9,7 \\
\hline \multirow{3}{*}{$\begin{array}{l}\text { In-service of training or participation in } \\
\text { ICT courses }\end{array}$} & Yes & & 88 & 40,6 \\
\hline & No & & 129 & 59,4 \\
\hline & & Total & 217 & 100 \\
\hline
\end{tabular}

\section{Data Collection Tools}

Data of the research were collected through "Individual Innovativeness Scale" and "Technology Acceptance Scale for Teachers". Also personal information form is used in order to provide demographic informations of the study group in research.

Individual Innovativeness Scale: In the research, "Individual Innovativeness Scale" was used for to state teachers' individual innovational features. Its original form was developed by Hurt, Joseph and Cook (1977). The scale was translated into Turkish by Kıliçer and Odabaş1 (2010). Individual innovativeness scale contains 12 positive and 8 negative items. While it was being translated into Turkish, it was seen that it had four factors "Resistance to change", "Opinion-leading", "Risk-taking" and "Openness to experience". Its variance explained for qualifications measurement has been analyzed. By the scale, innovativeness scores of attendees are calculated and attendees are categorized. If scores of attendees are between 80, attendees are innovators; if scores of attendees between 69 and 80, attendees are early adopters; if scores of attendees between 57 and 68, attendees are early majority; if scores of attendees between 46 and 56, attendees are late majority; if scores of attendees are less than 46 points, attendees are laggards. It also may be based on scores calculated by the scale of the overall assessment of individual levels of innovation. According to that score, 68 points higher individuals are regarded as highly innovative and individuals less than 64 points are interpreted as low in innovativeness. Analysis of results, reliability coefficient for the entire scale is 0.82 , "Resistance to change" factor regarding the reliability coefficient is 0.81 , "Opinion-leading" factor regarding the reliability coefficient is 0.73 , "Openness to experience" factor regarding the reliability coefficient is 0.77 and "Risk-taking" factor regarding the reliability coefficient is 0.62 . As a result of this study, analysis of the data obtained in, Cronbach's alpha reliability coefficient for the entire scale is 0.89 , the reliability coefficients of the factors respectively was calculated as $0.93,0.90,0.85$ and 0.90 .

Acceptance Scale for Teachers: The teaching-learning process to determine the status of teachers in technology acceptance "Technology Acceptance Scale for Teachers" is used was developed by Ursavaş, Şahin and Mcllroy (2014). This scale consists of 37 items within 11 factors. Scale items was collected under title of perceived usefulness (PU - 4 items), perceived ease of use (PEU - 3 items), attitude towards use (AT - 4 items), behavioral 
intention (BI - 4 items), facilitating conditions (FC - 3 items), perceived entertainment (PE - 4 items), self-efficacy (SE - 3 items), technological complexity (TC - 3 items), compatibility (C - 3 items), anxiety (A - 3 items) and subjective norms (SN - 3 items). In this study, all the factor loading figures range from 0.67 to 0.93 . According to the result relating to Cronbach's alpha reliability coefficient, the lowest factor found is 0.80 with self- efficiency and the highest factor for perceived entertainment is 0.91. As a result of analysis of the data obtained Cronbach's alpha reliability coefficient for the entire scale is 0.96 . The reliability coefficients of the factors respectively were calculated as $0.93,0.94,0.55,0.82,0.94,0.87,0.86,0.95$, 0.93 and 0.87 .

Personal Information Form: In this section which is called as personal information, questions which are aiming to obtain information about teachers' gender, educational background, type of school, age, seniority, instructional level which they work on, how long the information and communication technologies have been used by the teachers, how long the information and communication technologies have been used in the professional process by teachers and in-service training or the course participation of Information and the Communication Technologies.

\section{Data Analysis}

SPSS (Statistical Package for the Social Sciences) 10 packaged program was used to analyze the data obtained from "Individual Innovativeness Scale" and "Technology Acceptance Scale for Teachers" used for the collection of data in that study. Descriptive statistics and Pearson's coefficient of the correlation was used for analysis of data on the subgoals of the study.

\section{Findings}

First sub-goal of the research is to determine the level of teachers' individual innovativeness. It is devoted to the findings of the descriptive statistical analysis of the levels of teachers' individual innovativeness in Table 2.

Table 2. Descriptive statistics on the level of teachers' individual innovativeness

\begin{tabular}{lllllllc}
\hline & $\mathrm{N}$ & Mean & SD & Median & Mode & Skewness & Kurtosis \\
\hline $\begin{array}{l}\text { Individual } \\
\text { Innovativeness }\end{array}$ & 217 & 68,95 & 12,85 & 71 & 77 & $-0,87$ & 1,91 \\
\hline
\end{tabular}

According to the descriptive statistics for the scores obtained from the scale of individual innovativeness of 217 teachers in the study group, the mean of scores obtained is 68.95 and standard deviation is 12.85 . Based on these findings, the teachers' individual innovativeness characteristics can be said to be early adopters category. The distribution is shown based on teachers' individual innovativeness profile in Table 3.

Table 3. The distribution of individual innovativeness profile of teachers

\begin{tabular}{lcc}
\hline & $\mathrm{N}$ & $\%$ \\
\hline Laggards & 6 & 2,8 \\
\hline Late Majority & 27 & 12,4 \\
\hline Early Majority & 60 & 27,6 \\
\hline Early Adopters & 82 & 37,8 \\
\hline Innovators & 42 & 19,4 \\
\hline Total & 217 & 100,0 \\
\hline
\end{tabular}


Based on individual innovativeness profile in the table 3, it is seen that 42 teachers $(19.4 \%)$ are innovators , 82 teachers $(37.8 \%)$ are early adopters, 60 teachers $(27.6 \%)$ are early majority, 27 teachers $(12.4 \%)$ are late majority and 6 teachers $(2 \% 8)$ are laggards.

The second sub-goal of the research is to determine the status of technology acceptance of teachers. The findings of the descriptive statistical analysis belonging to the teachers' technology acceptance status are given in Table 4.

Table 4. Descriptive statistics related to technology acceptance status of teachers

\begin{tabular}{|c|c|c|c|c|c|c|c|}
\hline & $\mathrm{N}$ & Mean & SD & Median & Mode & Skewness & Kurtosis \\
\hline Technology acceptance status & \multirow{12}{*}{217} & 3,40 & 0,62 & 4,03 & 4,79 & $-0,86$ & 0,82 \\
\hline Perceived ease of use & & 4,19 & 0,76 & 4 & 4 & $-1,09$ & 1,42 \\
\hline Attitudes towards the use & & 4,15 & 0,83 & 4 & 5 & $-1,11$ & 1,00 \\
\hline Behavioral intention & & 4,20 & 0,80 & 4 & 5 & $-1,12$ & 1,34 \\
\hline Facilitating conditions & & 4,09 & 0,77 & 4 & 4 & $-0,85$ & 0,76 \\
\hline Perceived entertainment & & 4,20 & 0,75 & 4 & 4 & $-1,17$ & 1,89 \\
\hline Self-efficacy & & 4,24 & 0,68 & 4 & 4 & $-0,80$ & 0,73 \\
\hline Technological complexity & & 3,17 & 1,11 & 3,33 & 4 & $-0,31$ & $-0,77$ \\
\hline Compatibility & & 4,10 & 0,93 & 4 & 5 & $-1,09$ & 0,85 \\
\hline Anxiety & & 3,48 & 1,21 & 4 & 4 & $-0,48$ & $-0,95$ \\
\hline Subjective norms & & 3,93 & 0,84 & 4 & 4 & $-0,79$ & 0,21 \\
\hline Perceived Usefulness & & 4,19 & 0,88 & 4,4 & 5 & $-1,12$ & 0,45 \\
\hline
\end{tabular}

According to Table 4, status of teachers' technology acceptance seems to be at a good level (Mean=3.40). When examining the sub-dimensions related to technology acceptance status, it is seen to belong that the highest score of the mean is self-efficacy and the lowest score of the mean is technological complexity.

The third sub-goal of the study is to determine if there is a significant relationship between the teachers' the level of individual innovativeness and technology acceptance status of them. The findings of the descriptive statistical analysis belonging to the relationship between the level of teachers' individual innovativeness and technology acceptance status of them are given in Table 5 .

Table 5. Analysis of the relation between the level of teachers' individual innovativeness and technology acceptance status of them.

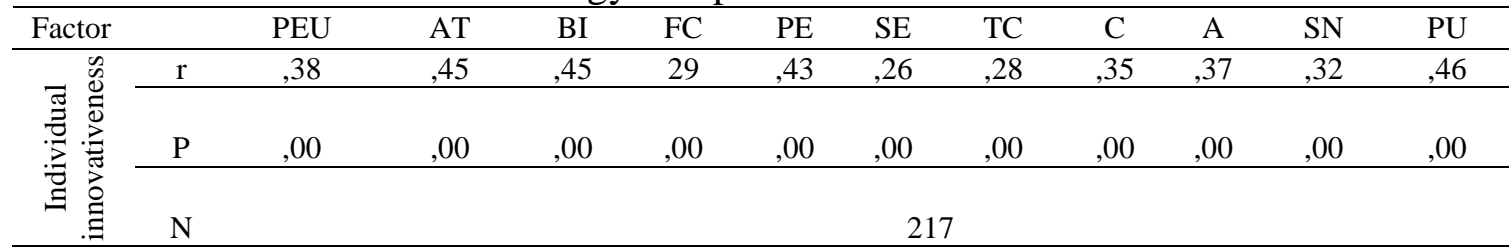

The result of simple correlation process which is performed to demonstrate whether there is a relationship between the sub-dimensions of the teachers' individual innovativeness characteristics and technology acceptance status of them showed that there are significant, low and medium level relationship between teachers' individual innovativeness characteristics and technology acceptance status of them $(\mathrm{p}<0,01)$. The dimension that shows the highest relation with teachers' individual innovativeness characteristics was determined as "perceived usefulness" $(\mathrm{r}=+0.46)$ and the dimension showing the lowest correlation with teachers' individual innovativeness characteristics was determined as "self-efficacy". According to the Table 5, It is seen that there are medium level, significant and positive 
correlation between teachers' individual innovativeness characteristics and perceived ease of use, attitude toward use, behavioral intention, perceived entertainment, compatibility, anxiety, subjective norms and perceived usefulness. On the other hand, it is seen that there are low level, significant and positive correlation between between teachers' individual innovativeness characteristics and facilitating conditions, self-efficacy and technological complexity.

\section{Conclusion and Recommendations}

The following results were obtained with this research which examined whether there is a significant relationship between the level of teachers' individual innovativeness, technology acceptance status of teachers and among these variables.

The teachers' individual innovativeness characteristics were determined to be early adopters category. According to that result, it can be said that teachers are individuals focused on technology that is providing information and guiding about innovations to other members of the community. In addition, teachers' technology acceptance status was found to be generally good level. In terms of sub-factors for teachers' technology acceptance status, it is determined that the highest level is self-sufficiency for the use of technology and the lowest level is technological complexity. According to that result, it can be said that teacher have positive thoughts for their ability to perform the job that teachers will use technology. On the other hand, it can be said that teacher had the perception that is the unstable level about their thoughts of the use and understanding of technology.

It is determined that there are low, medium and significant relationship between the level of teachers' individual innovativeness and technology acceptance status of them. the highest relation with teachers' individual innovativeness characteristics was determined as "perceived usefulness" and the lowest correlation with teachers' individual innovativeness characteristics was determined as "self-efficacy". Çuhadar, Bülbül and Ilgaz (2013) have stated that there is a relationship positive and medium level between the level of teachers' individual innovativeness and techno-pedagogical education competencies. In addition, Y1lmaz and Mutlu Bayraktar (2014) have found a positive and high level relationship between the attitude of teachers towards education technology and teachers' individual innovativeness. In the same way, Örün, Orhan, Dönmez and Kurt (2015) have found positive, significant and medium level relationship between scores of teachers' individual innovativeness and their technology attitudes. The obtained results are consistent with those studies.

Depending on the study conducted, increasing the number of teachers in the study group, to reveal teachers' individual innovativeness characteristics which may affect technology acceptance status of them with the qualitative studies and investigation of teachers' individual characteristics in terms of different variables are suggested.

\section{References}

Alkan, C. (1997). Eğitim Teknolojisi [Educational Technology]. Ankara: Anı Publishing.

Balay, R. (2004). Küreselleşme, bilgi toplumu ve eğitim [Globalization, Information Society and Education]. Ankara University Journal of Faculty of Educational Sciences, 37(2), 61-82

Celep, C. (2004). Meslek olarak ögretmenlik [Teaching as a Profession]. Ankara: Anı Publishing. 
Çelikten, M., Şanal, M. \& Yeni, Y. (2005). Öğretmenlik mesleği ve özellikleri [The teaching profession and features]. Erciyes University Journal of the Institute of Social Sciences, 19(2), 207-237.

Chen, F., Looi, C. \& Chen, W. (2009). Integrating technology in the classroom: A visual conceptualization of teachers' knowledge, goals and beliefs. Journal of Computer Assisted Learning, 25(5), 470-488.

Çuhadar, C., Bülbül, T. \& Ilgaz, G.(2013). Öğretmen Adaylarının Bireysel Yenilikçilik Özellikleri ile Teknopedagojik Eğitim Yeterlikleri Arasındaki İlişkinin İncelenmesi [Exploring of the Relationship between Individual Innovativeness and Technopedagogical Education Competencies of Pre-service Teacher]. Elementary Education Online, 12 (3), 797-807.

Dilaver, H. (1996). Türkiye'de öğretmen istihdamının dünü, bugünü ve yarını, eğitimimize baklşlar [Employment of teachers in Turkey: Yesterday, today and tomorrow, our perspective on education]. İstanbul: Kültür Koleji Vakfı Yayınları 1.

Drent, M. \& Meelissen, M. (2008) Which factors obstruct or stimulate teacher educators to use ICT innovatively?. Computers \& Education, 51, 187-199.

Fullan, M. \& Pomfret, A. (1977). Research on curriculum and instruction implementation. Review of Educational Research, 47(1), 335-397.

Fullan. M. (2007). The New Meaning of Educational Change. Fourth Edition. New York: Teachers' College Press.

Hu, P. J., Clark, T. H. K. \& Ma, W.W. (2003). Examining technology acceptence by school teachers: a logtudial study. Information \& Manegement, 41(2), 227-241.

Hurt, H. T., Joseph, K., \& Cook, C. D. (1977). Scales for the measurement of innovativeness. Human Communication Research, 4, 58-65.

Kabakcı, H. (2008). Eğitimde yenileşme çalışmaları ve öğretmenlerin ilçe milli eğitim müdürlüğü çalışmalarındaki yenileşme ve yeterliklere yönelik algı ve beklentileri (Kandıra Örneği) [The studies of innovation in education and the thoughts and expectations of teachers about these studies, that are performed by the ministry of education,in innovation and adequacies (The sample of Kandira)]. Unpublished master's thesis. Yeditepe University Institute of Social Sciences, İstanbul.

Karasar, N. (1999). Bilimsel araştırma yöntemi [Scientific research method]. Ankara: Nobel Publishing.

Kocasaraç, H. (2003). Bilgisayarların Öğretim Alanında Kullanımına İlişkin Öğretmen Yeterlilikleri [Teacher Qualifications Relevant to the Use of Computers in Instruction Area]. The Turkish Online Journal of Educational Technology, 2(3), 77-85.

Örün, Ö., Orhan, D., Dönmez, P. \& Kurt, A. A. (2015). Öğretmen adaylarının bireysel yenilikçilik profilleri ve teknoloji tutum düzeyleri arasındaki ilişkinin incelenmesi [Exploring the relationship between individual innovativeness and technology attitude of teacher candidate]. Trakya University Journal of Education, 5(1), 65-46.

Partnership for 21st Century Skills. (2003). Learning for the 21st century: A report and mile guide for 21st century skills. http://www.21stcenturyskills.org /images/stories/otherdocs/P21_Report.pdf

Partnership for 21st Century Skills. (2010). 21st century knowledge and skills in educator preparation. http://www.p21.org/documents/aacte_p21_whitepaper2010.pdf

Siraj-Blatchford, I. \& Siraj-Blatchford, J. (2003). More than Computers: Information and Communication Technology in the Early Years. London: The British Association for Early Childhood Education.

Şişman, M. (2006). Eğitim bilimine giriş [Introduction to Educational Sciences]. Ankara: Pegem Yayınevi. 
Teo, T. (2009) Modelling technology acceptance in education: A study of pre-service teachers. Computers \& Education, 52, 302-312

Tinio, V. L. (2003). ICT in Education. New York: Bureau for Development Policy.

Vanderlinde, R., \& van Braak, J. (2011). A New ICT Curriculum for Primary Education in Flanders: Defining and Predicting Teachers' Perceptions of Innovation Attributes. Educational Technology \& Society, 14 (2), 124-135.

Vanderlinde, R., \& van Braak, J. (2011). A New ICT Curriculum for Primary Education in Flanders: Defining and Predicting Teachers' Perceptions of Innovation Attributes. Educational Technology \& Society, 14(2), 124-135.

Y1lmaz, O. \& Mutlu Bayraktar, D. (2014). Teachers' attitudes towards the use of educational technologies and their individual innovativeness categories. Procedia-Social and Behavioral Sciences, 116, 3458-3461. 